\title{
Impairment of Water Quality of Phuleli Canal, Sindh Pakistan: A Review
}

\author{
MUHAMMAD WAJID IJAZ*, RASOOL BUX MAHAR*, GHULAM SHABIR SOLANGI*, \\ SALLAHUDDIN PANHWAR*, AND ABDUL KHALIQUE ANSARI* \\ RECEIVED ON 26.10.2016 ACCEPTED ON 21.02.2017
}

\begin{abstract}
Supply of quality water has been recognized as one of the water management practices. Clean water is not only essential for drinking and irrigation but also affects eco-services, groundwater aquifer and soil conditions. Hyderabad, a highly populated city of Pakistan is consuming large quantities of water and also disposing its untreated sewage and comingled solid waste in Phuleli canal. Similarly, many encroachments along the banks of Phuleli canal are directly impairing the water quality due to disposal of wastewater and other rejected materials. This canal irrigates Tando Muhammad Khan as well as some areas of district Badin. A review of many studies revealed that maximum of physio-chemical and biological parameters especially fecal Coliform (between 100-1600 MPN/100ml) and metal ions (Fe 1.90, Cd 0.004, Cr 0.082, Pb 0.045 and As $0.50 \mathrm{mg} / \mathrm{l}$ against WHO (World Health Organization) standards) were exceeding the prescribed permissible limits.This contaminated water is deteriorating the water quality and threatening the public health. Due to inadequate measures and apathy from responsible departments, water quality is being compromised especially during winter season, when low flows are released from Kotri Barrage, Kotri, Sindh. Without positive interventions and adherence of integrated approach, it is hard to ensure public health and sustainability of the canal system and agriculture depending upon this.
\end{abstract}

Key Words: Water Quality, Sewage, Fecal Coliform, Industrial Waste, Phuleli canal.

\section{INTRODUCTION}

$\mathrm{F}$ resh water, a valuable and limited natural resource on the earth is depleting very rapidly. Acute shortage of water is being governed by hydrometrological variations triggered by climate change and gross available water for utilization is under threat of quality impairment. Water demand is also increasing due to urban and economic development and improved living standards. Biological, chemical, physical and aesthetic parameters of water define its quality dimension. Healthy environment and beneficial use of water solely depends upon water quality.

Historically, poor water quality has been principally associated with public health concerns through transmission of water-borne diseases that are still major problems in Africa and in many other parts of the developing countries. In recent years, the contribution

${ }^{*}$ US-Pakistan Centers for Advanced Studies in Water, Mehran University of Engineering \& Technology, Jamshoro.

Mehran University Research Journal of Engineering \& Technology, Volume 36, No. 3, July, 2017 [p-ISSN: 0254-7821, e-ISSN: 2413-7219] 
of degraded water to the water crisis is also measured in loss of beneficial use that is lost for beneficial human, agricultural, and ecological uses through excessive pollution by pathogens, nutrients, heavy metals and acid mine drainage, trace organic contaminants such as agricultural pesticides and pesticides associated with wood treatment, and localized high levels of oil and related pollutants, including salt, hydrocarbons, metals and other toxic wastes, and high levels of turbidity and sedimentation from excessive loadings of sediments [1]. Urban water pollution has emerged as one of the most critical forms of environmental degradation in Asia. In Asian countries, water pollution is clearly an environmental and political issue. Water pollution, which is a common phenomenon in almost all Asian urban areas, results from the environmental impacts of urban growth, failure of regulations, and the increase of unplanned settlements with lack of basic sanitary and sewage systems. On the other hand, this is partly a result of the failure of the state institutions, weakness of central and local authorities and the historical negligence of environmental issues [2].

Pakistan, once having surplus water, is now a water deficit country. The main reasons for declining water availability are rapid population growth, depleting water storage facility, and pollution/contamination of existing water resources due to discharge of untreated industrial and sewage effluents in stream/rivers [3-5] reported serious public health problems due to the use of wastewater. Water borne diseases account for $20-30 \%$ of all the hospital cases and $60 \%$ of infant deaths [6]. In Pakistan, $64 \%$ of the population lives in rural area [7], most of them do not have the accessibility to good quality water; and due to use of polluted water, people face many diseases in such as typhoid, stomach infections, kidney problem, food poisoning and skin problem [8-9].

Hyderabad is second largest city in Sindh province of Pakistan, like other cities it is also facing lack of proper disposal of wastewater. Kotri Barrage is the last controlling structure constructed on the Indus River, built in the confluences of Hyderabad, Kotri and Jamshoro cities, in 1955 . The barrage was constructed to pass a maximum flow of 24,780 cumecs $(875,000$ cusecs). It is a source of domestic, industrial and irrigation water supply for an area of about 1.126 million hectares (2.78 million acres) and more than 25 million people. There are four canals off taking from Kotri Barrage, one from right bank and the rest from the left bank (http://sindh.gov.pk/dpt/Irrigation/ kotri\%20barrage.htm)as shown in Fig. 1.

Industrial waste from plastic factories, illegal cattle pens, slaughterhouses and untreated sewage is discharged indiscriminately into this canal from various points under gravity and/or pumping. From water distribution point of view this canal supplies water for irrigation and somehow for drinking purpose to residents of Badin, Tando Muhammad Khan districts of Sindh in Pakistan [10-11] reported that average quantity of effluents

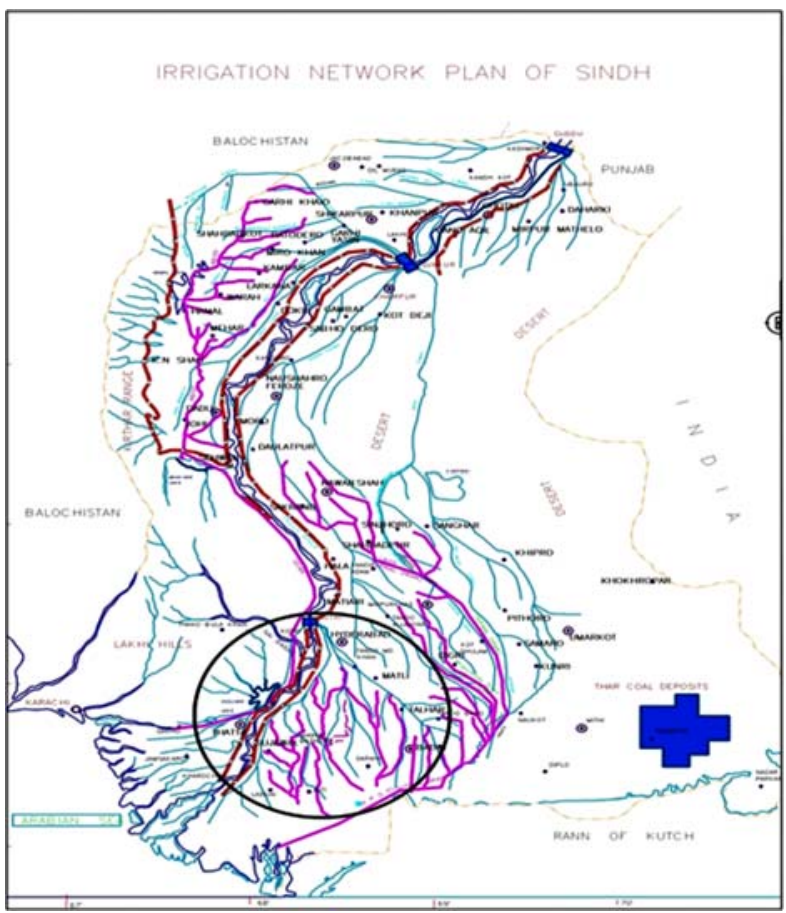

FIG. 1. OFF-TAKING PHULELI CANAL FROM KOTRI BARRAGE IN HYDERABAD CONFLUENCES

Mehran University Research Journal of Engineering \& Technology, Volume 36, No. 3, July, 2017 [p-ISSN: 0254-7821, e-ISSN: 2413-7219] 
drained into Phuleli canal from various sewage stations is $225584.44 \mathrm{~m}^{3}$ day $^{-1}$. There is more likelihood of impairment of water quality due to anthropogenic effects containing organic and inorganic matters, heavy metals, oil and grease, biological contaminants, industrial solvents and other toxicants.

This study was carried out in order to: investigate the physio-chemical and biological pollutants contaminating the canal water for construction of water quality profile, study the potential stressors of water quality deterioration and their seasonal variation along the reach and determine possible solutions for water quality management and mitigation of adverse environmental effects.

\section{WATER QUALITY PROFILE}

Water bodies can be fully characterized by the three major components: hydrology, physico-chemistry, and biology. A complete assessment of water quality is based on appropriate monitoring of these components [12]. There are thirteen locations on the left side and twenty-four locations on right side of the Phuleli canal where wastewater generated from small industries (cottage, plastic \& dyeing of Ajrak) and municipal areas is being discharged directly into the canal at the rate of 1 million gallons per day [13]. They reported that eight poultry farms were disposing solid waste and dead chicks in this canal, more than one hundred houses and numerous cattle farms in Pathan village were discharging untreated municipal wastewater. Similarly, at RD 20 on same reach, wastewater from Gumanabad settlement of 5000 people was being discharged containing wastewater at the rate 8 cusecs, garbage, manures and urine of cattle of this area is directly being disposed-off into canal.

\subsection{Physical Parameters}

These parameters specially related to reuse of water for domestic purposes. Odor, Color, Temperature, EC
(Electrical Conductivity), Turbidity, TDS (Total Dissolved Solids) and TSS (Total Suspended Solids) are physical parameters considered in this article. Besides other parameters, physical parameters were also changing with distance from head regulator.

\subsubsection{Taste and Odor}

Dissolved solids and gases especially form taste and odor in water. Organic material is considered predominant source of taste and odor. As, Phuleli canal receives municipal solid and liquid waste and pollution loading from cattle farms existing along its banks that is why analysis of canal water has undertaken [14] reveals that the Hyderabad city was giving objectionable odor. Sohag and Syed [13] have also ascertained that canal water at RD-34 near Ghangramori was odorous with objectionable level. However, results depicted in Table 1 are indicating that after crossing RD-62, canal water was unobjectionable. It is necessary to make water odor free if it is to be used for drinking purpose and taste must be acceptable.

\subsubsection{Color and Turbidity}

Number of factors make color of flowing water i.e. suspended sediments, decaying organic matter and dyes etc. As, Phuleli canal is open channel with earthen bed and banks, therefore, inflowing sediments, local erosion and disposal of municipal waste as well as animal dung is adding color to flowing water. Sohaq \& Syed [13] have revealed that color of canal water was greenish from RD20 to 34. Another study made by Soomro and Kumbhar [14] is showing that color of water closer to head regulator was clear while it was becoming darker as urban tertiary was interfacing with canal and up to RD-62, water was blackish. Turbidity more than 5 NTU was detectable with naked eye. Aesthetic condition of water was very poor as turbidity level was 28 NTU near Kotri Barrage and very turbid water was flowing near tail of this canal, as indicated in Table 1.

Mehran University Research Journal of Engineering \& Technology, Volume 36, No. 3, July, 2017 [p-ISSN: 0254-7821, e-ISSN: 2413-7219] 
drained into Phuleli canal from various sewage stations is $225584.44 \mathrm{~m}^{3}$ day $^{-1}$. There is more likelihood of impairment of water quality due to anthropogenic effects containing organic and inorganic matters, heavy metals, oil and grease, biological contaminants, industrial solvents and other toxicants.

This study was carried out in order to: investigate the physio-chemical and biological pollutants contaminating the canal water for construction of water quality profile, study the potential stressors of water quality deterioration and their seasonal variation along the reach and determine possible solutions for water quality management and mitigation of adverse environmental effects.

\section{WATER QUALITY PROFILE}

Water bodies can be fully characterized by the three major components: hydrology, physico-chemistry, and biology. A complete assessment of water quality is based on appropriate monitoring of these components [12]. There are thirteen locations on the left side and twenty-four locations on right side of the Phuleli canal where wastewater generated from small industries (cottage, plastic \& dyeing of Ajrak) and municipal areas is being discharged directly into the canal at the rate of 1 million gallons per day [13]. They reported that eight poultry farms were disposing solid waste and dead chicks in this canal, more than one hundred houses and numerous cattle farms in Pathan village were discharging untreated municipal wastewater. Similarly, at RD 20 on same reach, wastewater from Gumanabad settlement of 5000 people was being discharged containing wastewater at the rate 8 cusecs, garbage, manures and urine of cattle of this area is directly being disposed-off into canal.

\subsection{Physical Parameters}

These parameters specially related to reuse of water for domestic purposes. Odor, Color, Temperature, EC
(Electrical Conductivity), Turbidity, TDS (Total Dissolved Solids) and TSS (Total Suspended Solids) are physical parameters considered in this article. Besides other parameters, physical parameters were also changing with distance from head regulator.

\subsubsection{Taste and Odor}

Dissolved solids and gases especially form taste and odor in water. Organic material is considered predominant source of taste and odor. As, Phuleli canal receives municipal solid and liquid waste and pollution loading from cattle farms existing along its banks that is why analysis of canal water has undertaken [14] reveals that the Hyderabad city was giving objectionable odor. Sohag and Syed [13] have also ascertained that canal water at RD-34 near Ghangramori was odorous with objectionable level. However, results depicted in Table 1 are indicating that after crossing RD-62, canal water was unobjectionable. It is necessary to make water odor free if it is to be used for drinking purpose and taste must be acceptable.

\subsubsection{Color and Turbidity}

Number of factors make color of flowing water i.e. suspended sediments, decaying organic matter and dyes etc. As, Phuleli canal is open channel with earthen bed and banks, therefore, inflowing sediments, local erosion and disposal of municipal waste as well as animal dung is adding color to flowing "water”. Sohaq \& Syed [13] have revealed that color of canal water was greenish from RD-20 to 34. Another study made by Soomro and Kumbhar [14] is showing that color of water closer to head regulator was clear while it was becoming darker as urban tertiary was interfacing with canal and up to RD62, water was blackish. Turbidity more than 5 NTU was detectable with naked eye. Aesthetic condition of water was very poor as turbidity level was 28 NTU near Kotri Barrage and very turbid water was flowing near tail of this canal, as indicated in Table 1.

Mehran University Research Journal of Engineering \& Technology, Volume 36, No. 3, July, 2017 [p-ISSN: 0254-7821, e-ISSN: 2413-7219] 


\subsubsection{Total Dissolved and Suspended Solids}

Dissolved solids are measure of mineral contents present in water. TDS primarily contribute towards taste development of water. Suspended solids were mainly formed due to flowing of clayey material, organic matter and particles of solid waste. Concentration of dissolved solids generally defines salinity of a certain water and this phenomenon has been categorized as: fresh, 0-1000 mg/L; slightly saline, 1000-3000 mg/L; moderately saline, 3000$10000 \mathrm{mg} / \mathrm{L}$; very saline, $10000-35000 \mathrm{mg} / \mathrm{L}$; and briny, more than 35,000 mg/L. However, quality of Phuleli canal lies within category of fresh to slightly saline as enumerated in Table 1.

\subsubsection{Temperature and Electrical Conductivity}

It is measure of water to pass electric current. Concentration of salts and their ionization is governed by given temperature during analysis of EC. EC is one of the parameters which determines reusability of water for irrigation purposes. Results of Sohag and Syed [13], Soomro and Kumbhar 14] are suggesting respectively that there was no significant change in temperature of flowing water from head to tail. Therefore, these studies have also maintained that values of EC are far high as compared to limited defined by FAO (Food Agriculture Organization) for irrigation purposes.

\subsection{Chemical Parameters}

Water chemistry is considered one of the key issues while deciding reuse of treated water and fresh water from streams, canal or water courses. Where some chemical elements are present in water, even can cause hazard for beneficial use. Therefore, chemical parameters are discussed in this study under following three categories.

\subsubsection{Inorganic Characteristics}

\subsubsection{1 pH}

$\mathrm{pH}$ is basically a measure of acidity or alkalinity of a solution. It has been observed that $\mathrm{pH}$ of flowing water generally remains higher in winter and catching the lower value during summer and monsoon. Comparison of analysis has described [13-14] is describing that $\mathrm{pH}$ of the water was within limit of FAO for irrigation purpose but due to discharging of municipal and industrial waste, value started increasing. Both studies have maintained that $\mathrm{pH}$ is lying in between $6.8-7.5$ that are beyond the permissible level of FAO recommendations. Furthermore, $\mathrm{pH}$ increase also causes phytoplankton population growth.

\subsubsection{Phosphate}

Phosphate is essential from nutrition aspect but excess of phosphate blows the problem of eutrophication which is major cause of DO-depletion. Similarly supply of water containing high phosphates can affect the crop growth [3]. The values of phosphate shown in Table 1 [13-14] are indicating that this element is almost below the permissible limit set by WHO for drinking purpose.

\subsubsection{Bicarbonates and Hardness}

Carbonates and bicarbonates are one of the indicators for classification of raw water in terms of hardness. Values of bicarbonates and hardness tabulated in Table 1 are well below the limits prescribed by Pak-EPA and FAO for drinking and irrigation use respectively.

\subsubsection{Chlorides}

Noticeable taste is developed in drinkable water if concentration of Chloride exceeds $250 \mathrm{mg} / \mathrm{L}$. Domestic water should contain less than $100 \mathrm{mg} / \mathrm{L}$ of chlorides concentration [15]. However, chlorides directly contribute in making soils more saline and even high concentrations of it can inhibit the growth of plants. Similarly, availability of phosphorous to plants is also reduced due to presence of high concentrations of chlorides. Analysis undertaken by Mahar et. al. [16] is indicating that concentration of chlorides is increasing rapidly from 74-329 mg/L within reach length pf $11 \mathrm{~km}$ against limit set by FAO for irrigation.

Mehran University Research Journal of Engineering \& Technology, Volume 36, No. 3, July, 2017 [p-ISSN: 0254-7821, e-ISSN: 2413-7219] 


\subsubsection{Nitrite}

According to Metcalf [17], nitrate is used to measure the nutritional potential of certain water and it also gives an idea about oxidation. Generally, excess of nitrogenous content can burn the crop and deficiency can retard the plant growth. A study has been carried out that the apprising that except RD-30, water quality at remaining points was fit for irrigation. Even with slight removal of nitrites, it could be considered within limits of drinking water [13].

\subsubsection{Sulfate}

Presence of sulfates in raw water is one of the sources of odors like chlorine. Analysis of water samples conducted by Soomro and Kumbhar [14] is almost meeting the criteria on marginal sides for irrigation point of view but two samples of points namely near Saima plaza and Hoosri were having concentration high. It is more likely that due to disposal of highly polluted water, these points became vulnerable. Another study Sohag and Syed [13] has also indicated that sulfates concentration was high near RD34.

\subsubsection{Metals}

Metals in water are taken up while deciding the reusability of it. Excess of heavy metals can blow toxicity in water that is major hazard for entire biota and human consumption. Metal constituents in a stream are presumed present due to mixing of industrial pollutants. Soomro and Kumbhar [14] have determined that concentration of copper $(\mathrm{Cu})$, manganese $(\mathrm{Mn})$, zinc $(\mathrm{Zn})$, sodium $(\mathrm{Na})$, potassium $(\mathrm{K})$ and magnesium $(\mathrm{Mg})$ were increasing towards downstream of reach but $\mathrm{Na}$ and $\mathrm{K}$ were exceeding the desirable limits. Contrary to this trend nickel (Ni) is diluting towards $\mathrm{d} / \mathrm{s}$ and following the limit at the end.

According to Watto et. al. [11] Cu, K, Mg and Chromium (Cr) concentrations were increasing slightly but maximum metal contents were following the limits as depicted in
Table 1. However, concentration of Ni, Iron, Co, Mn, Zn, $\mathrm{Na}$ and Ca were diluting or decreasing as going farther from canal head regulator. $\mathrm{Mn}, \mathrm{K}, \mathrm{Na}$ and $\mathrm{Mg}$ content were high at some locations and but $\mathrm{Pb}$ content was not allowing to be used for drinking purpose without adequate treatment.

Moreover, another investigation has been conducted and explained that $\mathrm{Cu}, \mathrm{Ni}, \mathrm{Zn}$ and $\mathrm{Pb}$ concentrations were getting high towards downstream by following the prescribed limits but $\mathrm{Pb}$ level was unfit for drinking use [16]. Similarly, have apprised that concentrations Fe, $\mathrm{Na}$, $\mathrm{K}$, Ca, $\mathrm{Mg}$ and $\mathrm{Pb}$ were approaching lower values towards $\mathrm{d} / \mathrm{s}$. However, points where more contaminants loading were introduced were polluted in terms of $\mathrm{K}$ at $\mathrm{RD}-27, \mathrm{Na}$ at Hoosri and K persistently up to Nazarpur [14].

\subsubsection{Organic Chemical Characteristics}

Availability of oxygen in raw water is primarily governed by temperature, bio-chemical processes occurring in water due to presence of organic matter. Likewise, presence of oxygen plays a vital role in aerobic and anaerobic process for treatment. Low values of DO (Dissolved Oxygen) and high values of BOD (Biochemical Oxygen Demand) and COD (Chemical Oxygen Demand) are indication of polluted water. By comparing results of BOD and COD with NEQS (National Environmental Quality Standards) set by Pak-EPA (Pakistan Environmental Protection Agency), it has been observed that increasing towards $\mathrm{d} / \mathrm{s}$ but at the end of reach it gets a slight decline [13-14] but Mahar et. al. [16] showed that BOD and COD values were getting more higher towards $\mathrm{d} / \mathrm{s}$ in line with depletion of DO as shown in Table 1.

\subsection{Biological Parameters}

Pathogens and bacterial presence is confirmed with measurement of biological parameters. For supply of safe drinking water, biological characteristics are recognized key parameters because presence of biological contaminants enhances chances of communicable diseases. Following two parameters are available for assessment of health of water quality in Phuleli canal. 


\subsubsection{Microbial Contamination}

Positive results of bacteriological contaminants in every water sample except Seri and Tando Muhammad Khan is substantiating that without necessary treatment and disinfection, there was a great health risk for public which were depending upon it [14]. Another study by Sohag and Syed [13] has also confirmed that microbial contaminates were present in canal water.

\subsubsection{Fecal Coliform}

Presence of fecal coliforms in canal water shows that sewage has been mixed or discharged into this water body. Unfortunately, every sample resulted high quantity of fecal Coliform that is an alarming situation and threat to public health [14].

\section{SPATIO-TEMPORAL VARIATION OF WATER QUALITY}

Water demand and consumption rates keep changing with seasonal variegations due to fluctuating temperature, water availability and precipitation. Assessment of water quality on seasonal variation along the reach is a technique to study the trends of water pollution and impacts of point as well as non-point source pollutions [18]. Generally, high temperature and stream flows during monsoon and summer season give a benefit of natural dilution but on the other hand increase in temperature also affects kinetics of chemical process undergoing in canal. In the same manner, quantity of industrial effluents also varies in according to running season especially food processing units.

\subsection{Chemical Characteristics}

Limited number of studies was available for studying the seasonal variation of Phuleli canal water quality. A relative effect was determined by using water analysis from ground water in accordance to scheme shown in Fig. 2. They have concluded that due to low discharges into canal and less precipitation, ground water is getting more polluted during winter season. The ionic concentrations of electrical conductivity, Bi-carbonates, Chlorides, Calcium, Magnesium, Sodium and SAR was following increasing pattern towards $\mathrm{d} / \mathrm{s}$ during winter as shown in Table 2. However, seasonal variation is detected in following pattern (autumn > spring $>$ summer) [14].

\subsection{Metals and Traces}

Water quality of river depends upon assimilating or carrying capacity and it is affected by municipal and industrial wastewater, manure disposal and discharges from agriculture as well as paved roads and streets etc [19-20]. A single point along reach gives brief idea about water quality and its influencing factors like climate change impacts, anthropogenic effects and basin characteristics [21-23]. It is evident that there exists seasonal variation in concentrations of metals and traces in Phuleli canal. They have followed same locations of sampling as depicted in Fig. 2 and analysis was undertaken on same location with season's interval [14].

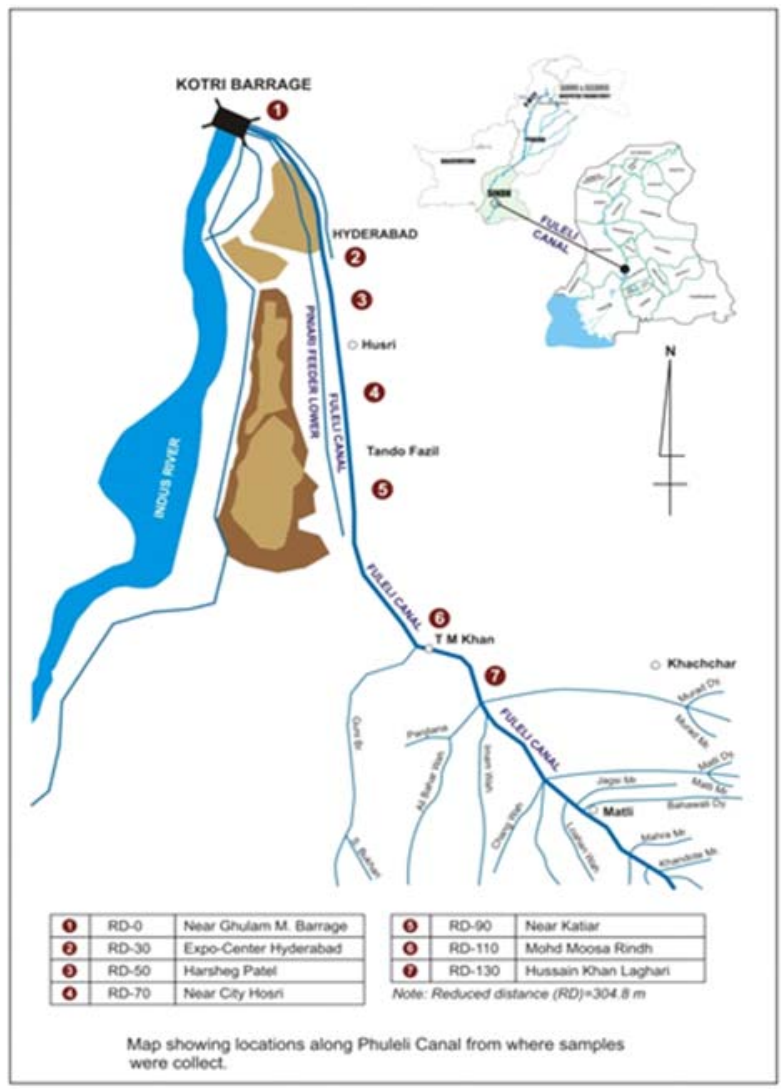

FIG. 2. LAYOUT OF PHULELI CANAL, ITS COMMAND AREA AND POINTS FROM WHERE WATER SAMPLES WERE DRAWN [14]

Mehran University Research Journal of Engineering \& Technology, Volume 36, No. 3, July, 2017 [p-ISSN: 0254-7821, e-ISSN: 2413-7219] 
As depicted in Table 3, concentrations of traces and metals were higher during winter due to low flows from river that ultimately reduces assimilating capacity of this canal. $\mathrm{Cd}, \mathrm{Cr}, \mathrm{Pb}$ and As concentrations were getting high values as going towards downstream in contrast to winter trend. However, seasonal changes also altered values and trends in following fashion (autumn>spring $>$ summer). Overall, water samples showed results beyond the desirable limits set by WHO for drinking water and FAO for irrigation of agricultural crops.

TABLE 2. SEASONAL VARIATION OF WATER QUALITY ALONG PHULELI CANAL REACH ON FIXED POINTS [14]

\begin{tabular}{|c|c|c|c|c|c|c|c|c|c|c|c|c|}
\hline \multirow{3}{*}{ Seasons } & \multirow{3}{*}{ Locations } & \multicolumn{9}{|c|}{ meql-1 } & \multirow{3}{*}{ SAR } & \multirow{3}{*}{ RSC } \\
\hline & & \multirow{2}{*}{$\mathrm{EC}(\mathrm{dS} / \mathrm{m})$} & \multirow{2}{*}{$\mathrm{pH}$} & \multicolumn{7}{|c|}{ meql-1 } & & \\
\hline & & & & CO3- & HCO3- & $\mathrm{Cl}$ & SO42- & $\mathrm{Ca} 2++\mathrm{Mg} 2+$ & $\mathrm{Na} 2+$ & $\mathrm{K}+$ & & \\
\hline \multirow{7}{*}{ Summer } & \begin{tabular}{|c|}
$\mathrm{RD}-0$ \\
(Regulator)
\end{tabular} & 2.14 & 7.59 & \multirow{7}{*}{ Nil } & 2.02 & 1098 & 10.27 & 7.23 & 15.37 & 0.68 & 8.09 & \multirow{7}{*}{ Nil } \\
\hline & RD-30 & 2.29 & 7.47 & & 2.34 & 11.57 & 9.74 & 7.04 & 15.98 & 0.63 & 8.52 & \\
\hline & RD-50 & 2.46 & 7.41 & & 2.57 & 12.95 & 10.20 & 7.93 & 17.23 & 0.56 & 8.66 & \\
\hline & $\mathrm{RD}-70$ & 2.68 & 7.40 & & 3.51 & 14.22 & 9.027 & 8.98 & 17.25 & 0.53 & 8.14 & \\
\hline & RD-90 & 3.27 & 7.34 & & 3.63 & 15.96 & 11.16 & 10.221 & 20.09 & 0.44 & 8.88 & \\
\hline & RD-110 & 3.64 & 7.28 & & 3.87 & 17.91 & 13.88 & 12.22 & 23.02 & 0.42 & 9.30 & \\
\hline & RD-130 & 4.54 & 7.21 & & 4.65 & 21.88 & 18.40 & 14.30 & 30.21 & 0.42 & 11.30 & \\
\hline \multirow{7}{*}{ Autumn } & $\begin{array}{c}\text { RD-0 } \\
\text { (Regulator) }\end{array}$ & 2.35 & 7.39 & \multirow{7}{*}{ Nil } & 2.55 & 11.34 & 11.6 & 7.99 & 16.54 & 0.64 & 8.27 & \multirow{7}{*}{ Nil } \\
\hline & RD-30 & 2.48 & 7.39 & & 2.54 & 11.93 & 10.97 & 7.67 & 17.19 & 0.58 & 8.78 & \\
\hline & RD-50 & 2.71 & 7.38 & & 2.77 & 13.98 & 10.72 & 8.69 & 18.26 & 0.52 & 8.76 & \\
\hline & RD-70 & 2.85 & 7.32 & & 3.67 & 17.78 & 6.72 & 9.58 & 18.11 & 0.48 & 8.28 & \\
\hline & RD-90 & 3.42 & 7.28 & & 3.85 & 16.97 & 13.78 & 11.78 & 22.43 & 0.38 & 8.25 & \\
\hline & RD-110 & 3.83 & 7.21 & & 4.02 & 18.83 & 14.86 & 12.98 & 24.36 & 0.37 & 9.56 & \\
\hline & RD-130 & 4.76 & 7.10 & & 4.86 & 22.92 & 20.27 & 15.69 & 31.98 & 0.38 & 11.42 & \\
\hline \multirow{7}{*}{ Winter } & \begin{tabular}{|c|}
$\mathrm{RD}-0$ \\
(Regulator)
\end{tabular} & 2.43 & 7.41 & \multirow{7}{*}{ Nil } & 2.33 & 11.94 & 11.321 & 8.21 & 16.77 & 0.61 & 8.28 & \multirow{7}{*}{ Nil } \\
\hline & RD-30 & 2.59 & 7.32 & & 2.67 & 12.02 & 11.66 & 7.96 & 17.83 & 0.56 & 8.94 & \\
\hline & $\mathrm{RD}-50$ & 2.78 & 7.31 & & 2.89 & 14.85 & 10.42 & 8.75 & 18.87 & 0.54 & 9.02 & \\
\hline & RD-70 & 2.96 & 7.28 & & 3.77 & 18.86 & 6.61 & 9.88 & 18.95 & 0.47 & 8.53 & \\
\hline & RD-90 & 3.52 & 7.20 & & 3.98 & 17.88 & 13.49 & 11.96 & 22.99 & 0.41 & 9.40 & \\
\hline & RD-110 & 3.97 & 7.18 & & 4.11 & 19.78 & 14.72 & 13.44 & 24.81 & 0.34 & 9.58 & \\
\hline & RD-130 & 4.88 & 7.12 & & 5.11 & 23.66 & 19.88 & 15.90 & 32.38 & 0.37 & 11.48 & \\
\hline \multirow{7}{*}{ Spring } & \begin{tabular}{|c|}
$\mathrm{RD}-0$ \\
(Regulator)
\end{tabular} & 2.23 & 7.49 & \multirow{7}{*}{ Nil } & 2.11 & 11.09 & 10.97 & 7.53 & 15.97 & 0.66 & 8.22 & \multirow{7}{*}{ Nil } \\
\hline & RD-30 & 2.40 & 7.42 & & 2.46 & 11.68 & 10.51 & 7.35 & 16.68 & 0.62 & 8.70 & \\
\hline & $\mathrm{RD}-50$ & 2.56 & 7.38 & & 2.65 & 13.23 & 10.44 & 8.08 & 17.79 & 0.56 & 8.85 & \\
\hline & RD-70 & 2.76 & 7.36 & & 3.66 & 16.89 & 7.23 & 9.38 & 17.86 & 0.52 & 8.24 & \\
\hline & RD-90 & 3.31 & 7.30 & & 3.72 & 16.28 & 14.15 & 10.87 & 20.83 & 0.42 & 8.93 & \\
\hline & RD-110 & 3.71 & 7.24 & & 3.98 & 18.31 & 14.68 & 12.65 & 23.94 & 0.39 & 9.52 & \\
\hline & RD-130 & 4.65 & 7.19 & & 4.79 & 22.23 & 19.25 & 14.90 & 30.98 & 0.39 & 11.34 & \\
\hline \multicolumn{2}{|c|}{ SE } & 0.0316 & 0.0058 & \multirow{4}{*}{ Nil } & 0.0633 & 0.0058 & 0.018 & 0.0058 & 0.0058 & 0.0058 & 0.0058 & \multirow{4}{*}{ Nil } \\
\hline \multicolumn{2}{|c|}{ LSD (5\%) } & 0.094 & 0.0172 & & 0.1879 & 0.0172 & 0.054 & 0.0172 & 0.0172 & 0.0172 & 0.0172 & \\
\hline \multicolumn{2}{|c|}{$*$ WHO } & - & $6.5-8.5$ & & - & 7.0 & 5.2 & - & 8.7 & 0.26 & 0.26 & \\
\hline & FO & $0-3$ & $6.5-8.4$ & & $0-10$ & $0-30$ & $0-20$ & 25 & 0.40 & - & $0-15$ & \\
\hline
\end{tabular}

Mehran University Research Journal of Engineering \& Technology, Volume 36, No. 3, July, 2017 [p-ISSN: 0254-7821, e-ISSN: 2413-7219] 
TABLE 3. SEASONAL VARIATION OF METALS AND TRACES ALONG PHULELI CANAL AND ITS COMMAND AREA [14]

\begin{tabular}{|c|c|c|c|c|c|c|c|c|c|}
\hline \multirow{2}{*}{ Seasons } & \multirow{2}{*}{ Locations } & \multicolumn{7}{|c|}{ Parameters (mg/L) } & \multirow{2}{*}{$\frac{\mathrm{gL}^{-1}}{\mathrm{As}}$} \\
\hline & & $\mathrm{Zn}$ & $\mathrm{Fe}$ & $\mathrm{Cu}$ & $\mathrm{Mn}$ & Cd & $\mathrm{Cr}$ & $\mathrm{Pb}$ & \\
\hline \multirow{7}{*}{ Summer } & $\begin{array}{c}\text { RD-0 } \\
\text { (Regulator) }\end{array}$ & 0.022 & 0.40 & 0.24 & 0.24 & 0.001 & $0.013 \mathrm{l}$ & 0.017 & 0.01 \\
\hline & $\mathrm{RD}-30$ & 0.027 & 1.57 & 0.25 & 0.38 & 0.001 & 0.016 & 0.017 & 0.017 \\
\hline & $\mathrm{RD}-50$ & 0.023 & 0.97 & 0.38 & 0.37 & 0.001 & 0.022 & 0.018 & 0.12 \\
\hline & $\mathrm{RD}-70$ & 0.020 & 0.68 & 0.54 & 0.26 & 0.001 & 0.037 & 0.021 & 0.16 \\
\hline & RD-90 & 0.018 & 0.55 & 0.69 & 0.35 & 0.002 & 0.036 & 0.024 & 0.17 \\
\hline & RD-110 & 0.018 & 0.50 & 0.72 & 0.35 & 0.002 & 0.043 & 0.022 & 0.20 \\
\hline & RD-130 & 0.013 & 0.42 & 0.72 & 0.28 & 0.002 & 0.052 & 0.024 & 0.29 \\
\hline \multirow{7}{*}{ Autumn } & $\begin{array}{c}\mathrm{RD}-0 \\
\text { (Regulator) }\end{array}$ & 0.039 & 0.75 & 0.13 & 0.127 & 0.001 & 0.027 & 0.024 & 0.17 \\
\hline & $\mathrm{RD}-30$ & 0.035 & 1.83 & 0.17 & 0.29 & 0.001 & 0.027 & 0.027 & 0.20 \\
\hline & $\mathrm{RD}-50$ & 0.032 & 1.65 & 0.22 & 0.28 & 0.002 & 0.045 & 0.026 & 0.18 \\
\hline & RD-70 & 0.026 & 0.98 & 0.36 & 0.25 & 0.002 & 0.057 & 0.028 & 0.22 \\
\hline & RD-90 & 0.026 & 0.88 & 0.38 & 0.26 & 0.003 & 0.057 & 0.030 & 0.26 \\
\hline & RD-110 & 0.023 & 0.78 & 0.45 & 0.23 & 0.003 & 0.066 & 0.032 & 0.28 \\
\hline & RD-130 & 0.021 & 0.88 & 0.55 & 0.23 & 0.004 & 0.071 & 0.032 & 0.37 \\
\hline \multirow{7}{*}{ Winter } & $\begin{array}{c}\text { RD-0 } \\
\text { (Regulator) }\end{array}$ & 0.041 & 1.35 & 0.083 & 0.12 & 0.002 & 0.036 & 0.029 & 0.20 \\
\hline & $\mathrm{RD}-30$ & 0.036 & 1.90 & 0.10 & 0.27 & 0.003 & 0.036 & 0.032 & 0.21 \\
\hline & RD-50 & 0.035 & 1.86 & 0.12 & 0.24 & 0.003 & 0.058 & 0.033 & 0.25 \\
\hline & RD-70 & 0.031 & 1.81 & 0.18 & 0.24 & 0.003 & 0.063 & 0.035 & 0.29 \\
\hline & RD-90 & 0.028 & 1.75 & 0.22 & 0.21 & 0.003 & 0.067 & 0.040 & 0.35 \\
\hline & RD-110 & 0.026 & 1.71 & 0.26 & 0.17 & 0.004 & 0.072 & 0.043 & 0.38 \\
\hline & RD-130 & 0.024 & 1.65 & 0.30 & 0.16 & 0.004 & 0.082 & 0.045 & 0.50 \\
\hline \multirow{7}{*}{ Spring } & $\begin{array}{c}\text { RD-0 } \\
\text { (Regulator) } \\
\end{array}$ & 0.034 & 0.66 & 0.17 & 0.15 & 0.001 & 0.017 & 0.019 & 0.11 \\
\hline & $\mathrm{RD}-30$ & 0.028 & 1.67 & 0.19 & 0.32 & 0.001 & 0.019 & 0.022 & 0.13 \\
\hline & RD-50 & 0.023 & 1.35 & 0.26 & 0.31 & 0.001 & 0.035 & 0.024 & 0.15 \\
\hline & $\mathrm{RD}-70$ & 0.023 & 0.88 & 0.45 & 0.29 & 0.002 & 0.047 & 0.025 & 0.18 \\
\hline & RD-90 & 0.020 & 0.66 & 0.57 & 0.28 & 0.002 & 0.047 & 0.026 & 0.22 \\
\hline & RD-110 & 0.020 & 0.65 & 0.66 & 0.27 & 0.003 & 0.053 & 0.028 & 0.24 \\
\hline & RD-130 & 0.020 & 0.59 & 0.75 & 0.25 & 0.003 & 0.063 & 0.028 & 0.33 \\
\hline \multicolumn{2}{|c|}{ SE } & 0.0059 & 0.0057 & 0.0058 & 0.0057 & 0.0059 & 0.0057 & 0.0056 & 0.006 \\
\hline \multicolumn{2}{|c|}{ LSD (5\%) } & 0.017 & 0.019 & 0.016 & 0.015 & 0.017 & 0.016 & 0.017 & 0.018 \\
\hline \multicolumn{2}{|c|}{ *WHO (mgL-1) } & 3.00 & 0.30 & 2.0 & 0.50 & 0.003 & 0.05 & 0.01 & 0.01 \\
\hline \multicolumn{2}{|c|}{ *FAO (mgL-1) } & 2.0 & 5.0 & 0.2 & 0.2 & 0.01 & 0.1 & 5.0 & 0.10 \\
\hline
\end{tabular}




\subsection{Soil Pollution}

A recent study on subsequent effects of polluted water on soil has revealed that due to continuous exposure of lands to polluted canal water is degrading the soil quality and very high values of metal ions have also been detected in soil those are potential cause of yield reduction in the field and can damage the soil texture [24].

\section{CONCLUSION}

Many encroachments along banks of Phuleli canal are directly impairing its water quality in addition to disposal of wastewater and other rejected materials. The main reasons for declining water availability are rapid population growth, lack of water storage facility and pollution/contamination of existing water resources due to disposal of untreated industrial and sewage effluents in stream/rivers. The contaminated water is deteriorating the water quality and causing threats to public health. Industries existing in the vicinity of Phuleli canal should be immediately restricted from disposal of any kind of waste. Irrigation \& Power Department, Government of Sindh is sole responsible for protection of quantity and quality of freshwater, thus it shall exercise its jurisdiction and devise a regular monitoring and enforcement mechanism for making positive deliberations in coordination with all stakeholders.

\section{RECOMMENDATIONS}

(i) A comprehensive survey would be undertaken for assessment of persisting trends of canal water pollution against different hydro-climatological scenarios based on pollution carrying and assimilation capacities. (ii) Hyderabad municipality should revisit its sewerage system and disposal stations should be connected with drainage network rather than canal.

(iii) Industry present in vicinity of this canal should be immediately restricted from disposal of untreated effluents by enforcing Environmental Protection Law and allied legal yard sticks.

(iv) All cattle farms should be made bound to adopt alternatives for prevention from disposal of animal dung etc. And vigilance should be kept upon poultry farms in order to stop illegal disposal of dead chicks into water body.

(v) Municipal solid waste should not be thrown in this fresh water body. Sindh Irrigation and Drainage Department is sole responsible for protection of quantity and quality of freshwater, so it would devise a regular monitoring and enforcing mechanism for making positive deliberations.

(vi) Mass awareness would be made possible for locals and all stake holders so that they stop drinking canal water without proper treatment and disinfection and also promote social responsibility of keeping environment clean and green.

\section{ACKNOWLEDGEMENTS}

Financial support by US Agency for International Development, Pakistan, and US-Pakistan Centres for Advanced Studies in Water, Mehran University of Engineering \& Technology, Jamshoro, Pakistan, are acknowledged. 


\section{REFERENCES}

[1] Ongley, E.D., "Water Quality Management: Design, Financing and Sustainability Considerations", Proceedings of the African Water Resources Policy Conference, Nairobi, World Bank, May 26-28, 1999.

Storey, D.,’Urban Water Pollution, Communities and the State in South Asia”, Workshop on Water in Mainland Southeast Asia, Siem Reap, 30 November to 2 December, 2005.

Kahlown, M.A., Ashraf, M., Hussain, M.,and Salam, H.A., "Impact Assessment of Sewerage and Industrial Effluents on Water Resources, Soil, Crops and Human Health in Faisalabad”, A Report by PCRWR, [ISBN-978-969-846917-7], 2006.

Blumenthal, U.J., Cifuentes E., Benett S., Quigley M., Ruiz-Palacouis G., "The Risk of Enteric Infectious Associated with Wastewater Reuse: The Effect of Season and Degree of Storage of Wastewater”, Transactions of the Royal Society of Tropical Medicine and Hygiene, Volume 96, pp. 131-137, 2001,

Shuval, H.I., Adin A., and Fattal, B.,’Transmission of Enteric Diseases Associated with Wastewater Irrigation: A Prospective Epidemiological Study”, Americal Journal of Public Health, Volume 79, pp. 850-852, 1989.

GOP, “Pakistan Economic Survey, 1999-2000”, Government of Pakistan Economic Adviser's Wing Finance Division, Islamabad, Pakistan, 2000.

WHO, "Data on Rural Population (\% of Total Population)”, 2012http://data.worldbank.org/indicator/ SP.RUR.TOTL.ZS

Ilyas, M., “Community Medicine Chains”, Industrial and Domestic Effluent and Living Organism, Public Health Reports, Washington, DC, USA, 1998.

Ilyas, M., Gilani, A.H., and Bhatty, N., "Study of Chemical Quality of Drinking Water Available to the Children of Different Schools of Ghulam Mohammad Abad, Faisalabad, Pakistan”, Pakistan Journal of Science, Volume 60, No. 1-2, pp. 26-30, 2008.
[10] Wattoo, M.H.S, Wattoo, F.H., Trimizi, S.A., Kazi, T.G., Bhanger, M.I., Mahar, R.B., and Iqbal, J., "Quality Characterization of Phuleli Canal Water for Irrigation Purpose”, The Nucleus, Volume 41, Nos. 1-4, pp. 69-75, 2004.

[11] Wattoo, M.H.S, Wattoo, F.H., Trimizi, S.A., Kazi, T.G., Bhanger, M.I., and Iqbal, J., "Pollution of Phuleli Canal Water in the City Permises of Hyderabad: Metal Monitoring”, Journal Chemistry Society of Pakistan, Volume 28, No. 2, pp. 136-143, 2006.

[12] WHO, "Water Quality Assessments - A Guide to Use of Biota, Sediments and Water in Environmental Monitoring”, 2nd Edition [ISBN: 0-419-21590-5 (HB) 0-419-21600-6 (PB)], 1996.

[13] Sohag, M.A., and Syed, M.A., "Pollution and Encroachment of Phuleli Canal along the Periphery of Hyderabad City of Pakistan”, American Journal of Biomedical Science [DOI: 10.5099/aj140200072], 2014.

[14] Soomro, M.S., and Kumbhar, M.I., "Quality Status of Phuleli Canal Water and its Suitability for Human Consumption”, Report by Badin Development and Research Organization, Badin \&Javahirul-Bukhari Foundation, Hyderabad, 2008.

[15] Davis, M.L., "Water and Wastewater Engineering”, McGraw-Hill, 2010.

[16] Mahar, R.B., Memon, A.R., and Misbahuddin, M., "Impact of Industrial Effluents on the Water Quality of Phulleli Canal”, Mehran University Research Journal of Engineering \& Technology, Volume 20, No. 1, pp. 37-42, Jamshoro, Pakistan, January, 2001.

[17] Metcalf, E., "Wastewater Engineering, Treatment and Reuse”, McGraw-Hill, New York, 2003.

[18] Ouyang, Y., Nkedi-Kizza, P., Wu, Q.T., Shinde, D., and Huang, C.H., “Assessment of Seasonal Variations in Surface Water Quality”, Water Research, Volume 40, No. 20, pp.3800-3810, 2006. 
[19] Stroomberg, G.J., Freriks, I.L., Smedes, F., and Co®no, W.P., "In Quality Assurance in Environmental Monitoring”, Quevauviller, P., andWeinheim, VCH, (Editors), 1995.

[20] Ward, A.D., and Elliot, W.J.,”In Environmental Hydrology”, Ward, A.D., and Elliot, W.J., (Editors), pp. 1, CRC Press, Boca Raton, 1995.

Bricker, O.P., and Jones, B.F., "Main Factors Affecting the Composition of Natural Waters”, Salbu, B.,Steinnes, E., (Editors), Trace Elements in Natural Waters, CRC Press, Boca Raton, FL, 1995.
Shrestha, S., and Kazama, F., "Assessment of Surface Water Quality using Multivariate Statistical Techniques: A Case Study of the Fuji River Basin”, Japanese Journal of Environment Modeling Software, Volume 22, No. 4, pp. 464-475, 2007.

[23] Ayers, R.S., and Westcot, D.W., "Water Quality for Agriculture”, FAOFood and Agriculture Organization of the United States, Rome Italy, 1985.

[24] Mastoi, G.M., Waryani, B., Laghari, Z.A., Palh, Z.A., Lashari, K.H., Almani, K.F., Rana, G., and Mastoi, A.W.,"Assessment of Chemistry of Soil Irrigated on Phuleli Canal”, Science Journal of Chemistry, Volume 2, No. 4, pp. 33-37, [doi: 10.11648/j.sjc.20140204.12], 2014. 